\title{
Sciendo
}

Acta Veterinaria-Beograd 2020, 70 (4), 484-496

Research article

UDK: 504.7:636.32/.38(497.113)

DOI: $10.2478 /$ acve-2020-0036

\section{ENVIRONMENTAL ASSESSMENT OF GREENHOUSE GASES EMISSION FROM SHEEP BREEDING IN VOJVODINA REGION OF SERBIA}

\author{
SAMARDŽIĆ M. Miljan", GALIĆ A. Zoran ${ }^{1}$, JAJIĆ M. Igor ${ }^{2}$, \\ LATKOVIĆ S. Dragana ${ }^{2 *}$, VASIN R. Jovica ${ }^{3}$, ANDREEVA V. Irina ${ }^{4}$, \\ VASENEV I. Ivan ${ }^{4}$
}

${ }^{1}$ Institute of Lowland Forestry and Environment, University of Novi Sad, Serbia; ${ }^{2}$ Faculty of Agriculture, University of Novi Sad, Serbia; ${ }^{3}$ Institute for Field and Vegetable Crops, Novi Sad, Serbia;

${ }^{4}$ Russian Timiryazev State Agrarian University, Moscow, Russia

(Received 27 January, Accepted 25 September 2020)

\begin{abstract}
The aim of this work is to show a calculation procedure for obtaining estimations for the carbon footprint of $1 \mathrm{~kg}$ of live weight of ewe, ram and lamb at the farm gate, taking into account regional typological features of agricultural production in agroecosystems. The methodology of carbon footprint (CF) calculation is based on the life cycle assessment (LCA) methodology developed for agricultural products. Results revealed that in modern technology of sheep breeding, $21.41 \mathrm{~kg} \mathrm{CO} 2$ e was emitted on average per $\mathrm{kg}$ of body weight of ewe, $19.13 \mathrm{~kg} \mathrm{CO} 2$ e was emitted on average per $\mathrm{kg}$ of body weight of ram, $3.2 \mathrm{~kg}$ CO2 e was emitted on average per $\mathrm{kg}$ of body weight of lamb. The main distinction of Vojvodina province is the low efficiency of fertiliser application on crop fields and manure management, storage and utilisation, which has as a result high emissions of nitrous oxide. This is the field where the implementation of intensive technologies of precise farming, manure handling, utilisation and management will significantly decrease GHG emission, with preserving yield of crops and quantity and quality of sheep of all categories.
\end{abstract}

Key words: environmental assessment, sheep breeding, fertilisers, agro-ecosystems, carbon footprint

\section{INTRODUCTION}

Ever-increasing human population represents a major challenge for modern society, and anthropogenic pressure on ever decreasing natural resources is one of the major problems of environmental science. Anthropogenic greenhouse gases (GHGs) emission is one of the most prominent ecological issues within this problem. In addition, the population boom is setting a task to agriculture, that is the production of sufficient quantities of safe food for the constantly growing number of humans,

*Corresponding author: e-mail: dragana@polj.uns.ac.rs 
with the efficient use of the limited quantity of natural resources [1-4]. Global anthropogenic greenhouse gas emissions were increased by $70 \%$ between 1970 and 2004, and continue to rise, despite consistent evidence that this increase has caused discernible changes in the global climate since the mid-20 $0^{\text {th }}$ century. Agriculture as such is contributing to the global GHG emission with $16 \%$ of total global emission (or $32 \%$ if emission from land use change is counted) [1,5-7]. This puts agriculture in the same level of GHG emitters with other sectors of human activity: energy generation $-26 \%$, industry $-19 \%$, transport - 13\% [8]. Methane, carbon dioxide and nitrous oxide are exhibiting different greenhouse effects, and because of that their impact is calculated through the global warming potential (GWP) which comparable effects of particular greenhouse gas with that of $\mathrm{CO}_{2}$ in a 100 -year period. GWP of carbon dioxide is 1, the GWP of methane is 23 and the GWP of nitrous oxide is 296 (i.e., $1 \mathrm{~kg}$ of methane has an effect as same as $23 \mathrm{~kg}$ of carbon-dioxide etc.) [9]. The carbon footprint (CF) represents the amount of GHGs released during production of unit of some goods or services, represented in $\mathrm{kg} \mathrm{CO}_{2}$ equivalent $\left(\mathrm{kg} \mathrm{CO} \mathrm{CO}_{2}\right.$.), and it is calculated by multiplying the amount of specific gas with corresponding global warming potential of a given gas ( 1 for $\mathrm{CO}_{2}, 23$ for $\mathrm{CH}_{4}$ and 296 for $\mathrm{N}_{2} \mathrm{O}$ ) [10].

In the past few years, efforts have been made to make a comparative evaluation of agricultural production and its impact on the environment. In order to monitor and stimulate the reduction of greenhouse gas emissions in developed countries, systems of food products certification in terms of specific greenhouse emissions are actively developing and implementing. In Europe, those systems of environmental certification are used for improving of the economic competitiveness of the ecologically produced food [11].

Not all agricultural products are of the same biological value for human nutrition, because humans are in need of high quality proteins in the diet for normal growth, development and sustenance of life. Basically, the main source of these proteins is meat, which is produced from domestic animals, and because of that the livestock sector is producing more GHGs than other sectors of food production, mainly methane and nitrous oxide $[3,8,12]$. Up to $14.5 \%$ of global GHG emissions are attributed to livestock production when land use is not included $[9,10]$. Meat of ruminant origin is much more emission intensive than meat of non-ruminants, because of intensive enteric fermentation [10,13], and meat from ruminants held on pasture is additionally burdened by $\mathrm{N}_{2} \mathrm{O}$ emission from the applied nitrogen fertilizer and manure. Also, when assessing GHG emissions and solutions for their mitigation, not only specific sources of GHG must to be taken into account (for example: methane emission from the rumen, and as a method for its mitigation the reduction in quantity of roughage and increase in quantity of cereals), but the whole phase in production or the system as whole (aforementioned reduction in methane emission from the rumen may be followed by increased emission of nitrous oxide from fertilisers used in the cereal production). Also, the farm gate is given as a boundary because 70 to $90 \%$ of the emissions in the total chain occur before the products leave the farm gate [14]. 
In the Vojvodina region, more intensive stable system is the main type of sheep breeding, and meat breeds constitute more than $90 \%$ of total number of animals (namely Merinolandschaf which is represented with $67 \%$ and Île-de-France sheep with $24 \%$ of the total number of animals). Also, average size of the herd per farmer is 41 animals. Ordinary farm in Vojvodina region stacks 10 ewes per hectare, with average weaning of 1.7 lambs. First mating for the ewes is at the age of 10-12 months, and average reproductive life is 4 lambings, which gives a production of 6.8 lambs per ewe. In Vojvodina region, lambs are slaughtered at the age of 6 months, and ewes and rams at the average age of three and a half years. Average slaughter weights of animals are: lambs $30 \mathrm{~kg}$, ewes $75 \mathrm{~kg}$, rams $120 \mathrm{~kg}$ [16].

\section{MATERIAL AND METHODS}

Typically the Carbon Footprint (CF) calculation is based on the life cycle assessment (LCA) methodology, i.e. the calculation of emissions that take place throughout the life cycle of a product from the production of the raw materials up to the disposal (principle "from cradle to grave"). The calculation takes into account each stage and includes the transport within the production chain from the first step up to the defined border of the system (the end of the chain).

The CF was established as a generic indicator of a product, primarily aimed at the impact determination of industrial products. Rules and procedures of calculation are internationally standardised through the ISO standards for LCA $[17,18]$.

Methodology described in this article is based on the United Nations Food and Agriculture (FAO) LCA guidelines for small ruminants [19], supplanted by IAGRICO $_{2}$ calculator [20].

The concept of LCA can be divided into 4 main phases:

- definition of aim and scope;

- life cycle inventory;

- life cycle impact assessment;

- interpretation.

\section{Definition of aim and scope}

The aim of this study is to show a calculation procedure for obtaining estimations for the carbon footprint of an agricultural product, namely $1 \mathrm{~kg}$ of body weight of ewe, ram and lamb at the farm gate, taking into account regional typological features of agricultural production in agro-ecosystems of Vojvodina province. The system boundary included both primary breeding processes (rearing and feeding) and background processes (fertiliser production, fuel and energy). Buildings and machinery were excluded from this analysis, because their specific CF, when distributed through their entire lifetime, contributes to the total CF negligibly. 


\section{Life cycle inventory}

GHG emission from land use change will not be taken into account, because there is insufficient data in this moment on that topic in Serbian science. The main soil type of Vojvodina province is chernozem, carbonated, micellar, and additional application of lime to the soil is not needed. In order to comply with LEAP guidelines, carbon sequestration was considered to be at equilibrium.

Emissions from enteric fermentation for adult animals were calculated as $6.5 \%$ of gross energy intake (GEI). For lambs, no enteric $\mathrm{CH}_{4}$ emissions were estimated for the first month post lambing. From week 5, enteric $\mathrm{CH}_{4}$ emission was estimated as $4.5 \%$ of lambs GEI [21].

Methane emission from manure was obtained using the method described by the IPCC [21] and data from [12, 22, 23]. Application of solid manure on the field is releasing minimal quantities of methane, and will be excluded from calculation.

Data about $\mathrm{N}_{2} \mathrm{O}$ emission were obtained using the method described by the IPCC [21], from experiments performed in Russia [12], and from empirical data obtained through field research in central Bačka region of Vojvodina.

Data on GHG emission from fuel and energy were based on data IPCC [21,24] and Ecoinvent database of Swiss Centre for Life Cycle Inventories [25]. In addition, complex data were obtained through LISSOZ software application.

\section{Life cycle impact assessment}

In purpose of the working LCA algorithm's preparation, perspectives of GHG emission mitigation must be taken into consideration.

For more systematic and optimized data processing, sheep farm production can be divided into 2 phases:

- Phase 1: Feed and Crop production

- Phase 2: Livestock production

As a functional unit, $1 \mathrm{~kg}$ of body weight of ewe, ram and lamb at the farm gate will be used.

\section{RESULTS}

\section{Phase 1: Feed and Crop production}

Individual components of feed have different CF (Tab. 5), and animals are not consuming equal amount of each component. To calculate $\mathrm{CF}$ of feed both quantities of consumed components (Tab. 1) as well as amount of fuel and fertiliser used in the specific crop production process and their representative CF need to be determined, as well as CF of pesticides (Tab. 2, 3 and 4) [24]. Data on fuel consumption were obtained through Cooperative Union of Vojvodina's datasheets. 
Table 1. Total quantity of feeds used by individual categories of animals (per animal)

\begin{tabular}{lcccccc}
\hline Categories of animals & \multicolumn{7}{c}{ Feeds (kg) } \\
\cline { 2 - 7 } & $\begin{array}{c}\text { Maize } \\
\text { corn }\end{array}$ & $\begin{array}{c}\text { Sunflower } \\
\text { meal }\end{array}$ & Wheat & Barley & Triticale & $\begin{array}{c}\text { Hay } \\
\text { (50\% Alfalfa) }\end{array}$ \\
\hline Young lambs & 0.36 & 0.9 & 0 & 0 & 0 & 3 \\
Lambs for fattening & 35.4 & 11.76 & 0 & 0 & 0 & 200 \\
$\begin{array}{l}\text { Lambs for reproduction } \\
\text { (above 6 months of age) }\end{array}$ & 40 & 23.5 & 11 & 10 & 0 & 550 \\
Ewes & 265 & 165 & 66 & 135 & 33 & 850 \\
Rams & 800 & 270 & 0 & 0 & 0 & 1050 \\
\hline
\end{tabular}

Table 2. Carbon footprint of fertilisers per kilogram of feed (yield per www.stat.gov.rs)

\begin{tabular}{lcccc}
\hline Crops & $\begin{array}{c}\text { Yield } \\
\left(\mathbf{t ~ h a}^{-1}\right)\end{array}$ & $\begin{array}{c}\text { Applied Nitrogen } \\
\text { per hectare }(\mathbf{k g})\end{array}$ & $\begin{array}{c}\text { GHG emissions per } \\
\text { hectare }\left(\mathbf{k g ~ C O}_{\mathbf{2}} \mathbf{e}\right)\end{array}$ & $\begin{array}{c}\text { GHG emissions per } \\
\mathbf{k g} \text { of feed }\left(\mathbf{k g ~ C O}_{\mathbf{2}} \mathbf{e}\right)\end{array}$ \\
\hline Maize & 7.3 & 180 & 1826.1 & 0.25 \\
Sunflower meal (soya) & 3.3 & 50 & 507.25 & 0.15 \\
Wheat & 4.6 & 130 & 1318.85 & 0.29 \\
Barley & 3.9 & 140 & 1420.3 & 0.36 \\
Triticale & 4.2 & 150 & 1521.75 & 0.36 \\
Alfalfa & 11 & 50 & 608.7 & 0.01 \\
\hline
\end{tabular}

Table 3. Carbon footprint of fuel and energy per kilogram of feed (yield per www.stat.gov.rs)

\begin{tabular}{lcccc}
\hline Crops & $\begin{array}{c}\text { Yield } \\
\left(\mathbf{t ~ h a}^{-1}\right)\end{array}$ & $\begin{array}{c}\text { Annual quantity } \\
\text { of diesel fuel per } \\
\text { hectare (litres) }\end{array}$ & $\begin{array}{c}\text { GHG emissions per } \\
\text { hectare }\left(\mathbf{k g ~ C O}_{\mathbf{2}} \mathbf{e}\right)\end{array}$ & $\begin{array}{c}\text { GHG emissions per } \\
\mathbf{k g} \text { of feed (kg CO } \mathbf{~} \mathbf{~})\end{array}$ \\
\hline Maize & 7.3 & 120 & 316.8 & 0.04 \\
Sunflower meal (soya) & 3.3 & 116 & 306.24 & 0.09 \\
Wheat & 4.6 & 92 & 242.88 & 0.05 \\
Barley & 3.9 & 90 & 237.6 & 0.06 \\
Triticale & 4.2 & 92 & 242.88 & 0.06 \\
Alfalfa & 11 & 74 & 195.36 & 0.01 \\
Grass hay & 2 & 18 & 47.52 & 0.02 \\
\hline
\end{tabular}


Table 4. GHG emissions due to pesticides application per kilogram of crop yield (yield per www.stat.gov.rs)

\begin{tabular}{lccc}
\hline Crops & $\begin{array}{c}\text { Yield } \\
\left(\mathbf{t ~ h a}^{-1}\right)\end{array}$ & $\begin{array}{c}\text { GHG emissions per } \\
\text { hectare (kg CO } \mathbf{~ e q . ~}\end{array}$ & $\begin{array}{c}\text { GHG emissions per kg of } \\
\text { crop yield (kg CO } \mathbf{~ e q . ~}\end{array}$ \\
\hline Maize & 7.30 & 689.18 & 0.09 \\
Sunflower meal (soya) & 3.30 & 531.62 & 0.16 \\
Wheat & 4.60 & 197.38 & 0.04 \\
Barley & 3.90 & 197.38 & 0.05 \\
Triticale & 4.20 & 197.38 & 0.05 \\
Alfalfa & 11.00 & 110.81 & 0.01 \\
\hline
\end{tabular}

Table 5. Carbon footprint of individual crops in $\mathrm{kg} \mathrm{CO}_{2}$ eq

\begin{tabular}{lcccc}
\hline Crops & $\begin{array}{c}\text { GHG emissions } \\
\text { from fertiliser use } \\
\text { per kg of yield }\end{array}$ & $\begin{array}{c}\text { GHG emissions from GHG emissions from } \\
\text { fo of yield }\end{array}$ & $\begin{array}{c}\text { Carbon } \\
\text { kg ondicides application } \\
\text { footprint of } \\
\text { individual crop }\end{array}$ \\
\hline Maize & 0.25 & 0.04 & 0.09 & 0.38 \\
\hline $\begin{array}{l}\text { Sunflower } \\
\text { meal (soya) }\end{array}$ & 0.15 & 0.09 & 0.16 & 0.4 \\
Wheat & 0.29 & 0.05 & 0.04 & 0.38 \\
Barley & 0.36 & 0.06 & 0.05 & 0.47 \\
Triticale & 0.36 & 0.06 & 0.05 & 0.47 \\
\hline Alfalfa & 0.01 & 0.01 & 0.01 & 0.03 \\
Grass hay & 0 & 0.02 & 0 & 0.02 \\
\hline
\end{tabular}

Table 6. GHG emission due to the consumed feed per animal category in $\mathrm{kg} \mathrm{CO}_{2}$ eq.

\begin{tabular}{lccccccccc}
\hline & $\begin{array}{c}\text { Maize } \\
\text { corn }\end{array}$ & $\begin{array}{c}\text { Sunflower } \\
\text { meal } \\
\text { (soya) }\end{array}$ & Wheat & Barley & Triticale Alfalfa & $\begin{array}{c}\text { Grass } \\
\text { hay }\end{array}$ & $\begin{array}{c}\text { GHG } \\
\text { emission } \\
\text { from feed } \\
\text { production }\end{array}$ & $\begin{array}{c}\text { GHG } \\
\text { emission per } \\
\text { kg of body } \\
\text { weight }\end{array}$ \\
\hline Ewes & 330.89 & 212.46 & 86.24 & 195.05 & 46.53 & 49.54 & 33.03 & 953.75 & 12.72 \\
\hline Rams & 940.79 & 338.46 & 4.18 & 4.7 & 0 & 58.54 & 39.03 & 1385.7 & 11.55 \\
\hline Lambs & 13.59 & 5.06 & 0 & 0 & 0 & 3.04 & 2.03 & 23.72 & 0.79 \\
\hline
\end{tabular}

Nutrition rations for different categories of lambs and ewes are based on maize corn, sunflower meal, wheat, triticale and barley. Voluminous feeds in stable systems are mix of grass and alfalfa hay, in equal proportions. Maize silage is generally not used in feeding. In pasture system, natural pastures are not fertilised at any way, except naturally with sheep excrement. 
Sunflower meal is a by-product of edible oil extraction, so its CF is calculated as a substitute $\mathrm{CF}-\mathrm{CF}$ of the sunflower meal is replaced by CF of the feed which it substituted in 1:1 ratio (in this particular case soybean).

GHG emissions of the feed per animal category: From data on feed consumption (Tab. 1) and data on CF of individual feed components (Tab. 5), data on total GHG emission from feeding were obtained (Tab. 6).

\section{Phase 2: Livestock production}

In the phase of livestock production, the main sources of GHG emission are enteric fermentation, manure and manure management and fuel and energy consumption needed for feeding and accommodation of the animals.

Methane emission from enteric fermentation: The calculation of methane emission from enteric fermentation (EF) is based on recommendations from IPCC [21], Tier 2. For ewes and rams, $6.5 \%$ of gross energy intake is released into atmosphere in form of methane, and for lambs $4.5 \%$ of gross energy intake $\left(\mathrm{Y}_{n}\right)$. Lamb enteric $\mathrm{CH}_{4}$ emissions were calculated to begin at 35 days of age Gross energy intake day ${ }^{-1}$ (GE) of typical concentrated feed ratio for ewes has $5.63 \mathrm{MJ}$, for rams 11,26 MJ and for lambs 2.67 MJ on average. Gross energy intake day ${ }^{-1}$ from hay is for ewes $9.54 \mathrm{MJ}$, for rams 12.1 MJ and for lambs 4.32 MJ on average (Tab.7).

Table 7. Methane emission from enteric fermentation

\begin{tabular}{lccccc}
\hline & Ym & GE & EF & $\begin{array}{c}\text { Lifetime methane } \\
\text { emission }(\mathbf{k g})\end{array}$ & $\begin{array}{c}\text { Emission in } \mathbf{~ k g} \\
\mathbf{C O}_{2} \text { eq. }\end{array}$ \\
\hline Ewes & 0.065 & 15.17 & 1.77 & 5.88 & 135.24 \\
Rams & 0.065 & 23.36 & 2.73 & 8.19 & 188.37 \\
Lambs & 0.045 & 6.99 & 0.57 & 0.28 & 6.555 \\
\hline
\end{tabular}

GHG emissions from manure storage and application in Vojvodina region are almost exclusively composed from $\mathrm{N}_{2} \mathrm{O}$ which is emitted as a by-product of the process of the denitrification of manure's nitrogen compounds. Total excreted quantity of nitrogen and GHG emission per animal's lifetime is shown in the Tab. 8.

Table 8. Nitrogen content excreted through manure during animal's lifetime and GHG emission from manure

\begin{tabular}{lcc}
\hline & Quantity of Nitrogen $\mathbf{( k g )}$ & GHG emission $\mathbf{( k g ~ C O}$ eq.) \\
\hline Ewes & 203.67 & 301.43 \\
Rams & 341.88 & 505.98 \\
Lambs & 26.28 & 38.89 \\
\hline
\end{tabular}


GHG emissions from fuel and energy used in feeding and accommodation: Average consumption of diesel fuel per lifetime of the ewe amounts to 60 litres, which is equal to the $157.8 \mathrm{~kg} \mathrm{CO} 2$ eq.

Total amount of electricity consumption per ewe is $72 \mathrm{kWh}$. or $57 \_\mathrm{kg} \mathrm{CO}$ e is released in animal's lifetime.

GHG emission from phase of livestock production: All given emissions (enteric fermentation, manure storage, energy and electricity consumption) are shown in Tab. 9.

Table 9. GHG emission from phase of livestock production ( $\mathrm{kg} \mathrm{CO}_{2}$ eq.)

\begin{tabular}{lccccc}
\hline & $\begin{array}{c}\text { GHG emission } \\
\text { from enteric } \\
\text { fermentation }\end{array}$ & $\begin{array}{c}\text { GHG } \\
\text { emission from } \\
\text { fuel and energy }\end{array}$ & $\begin{array}{c}\text { GHG } \\
\text { emission } \\
\text { from } \\
\text { electricity }\end{array}$ & $\begin{array}{c}\text { GHG } \\
\text { emission from } \\
\text { manure }\end{array}$ & $\begin{array}{c}\text { GHG emission } \\
\text { from phase } \\
\text { of livestock } \\
\text { production }\end{array}$ \\
\hline Ewes & 135.24 & 157.8 & 57 & 301.43 & 8.69 \\
Rams & 188.37 & 157.8 & 57 & 505.98 & 7.58 \\
\hline Lambs & 6.555 & 19.73 & 7.12 & 38.89 & 2.41 \\
\hline
\end{tabular}

From all given data, CF of the animal at the farm gate can be calculated (Tab. 10).

Table 10. Carbon footprint of ewes, rams and lambs at the farm gate

\begin{tabular}{|c|c|c|c|}
\hline & $\begin{array}{l}\mathrm{CF} \text { from phase of livestock } \\
\text { production (kg CO} 2 \text { eq.) }\end{array}$ & $\begin{array}{l}\mathrm{CF} \text { of Feed } \\
\left(\mathrm{kg} \mathrm{CO} \mathrm{C}_{2} \text { eq.) }\right.\end{array}$ & $\begin{array}{l}\text { CF of Animal at Farm } \\
\text { Gate (kg CO}{ }_{2} \text { eq.) }\end{array}$ \\
\hline Ewes & 8.69 & 12.72 & 21.41 \\
\hline Rams & 7.58 & 11.55 & 19.13 \\
\hline Lambs & 2.41 & 0.79 & 3.2 \\
\hline
\end{tabular}

\section{DISCUSSION}

According to the performed analysis of the GHG emissions' basic sources in the Life Cycle of the sheep breeding, the conclusion was made that the most efficient mean for the greenhouse gases emission evaluation and assessment is integral algorithm of GHG emission calculation, which is divided into 2 phases of the LCA: (1) feed and crop production, and (2) livestock (sheep) production. Every phase is characterized by specific emission factors. Regulation of those emission factors is providing us with means for reduction of this specific anthropogenic impact on the environment.

Phase 1: Feed and Crop production: GHG emissions in this phase are dominated by $\mathrm{CO}_{2}$ from fuel consumption, and $\mathrm{N}_{2} \mathrm{O}$ emissions as a result of the fertiliser production and application as well as transformation of the ammonia from the applied manure to nitrates followed by processes of denitrification. 
Calculation of fertiliser CF is complex, because there are two steps in it: calculation of fertiliser production's CF [26] and amount of $\mathrm{N}_{2} \mathrm{O}$ of fertiliser origin emitted from soil $[10,21,22,27,28]$. Also, urea is emitting $\mathrm{CO}_{2}$ as well [21]. Fuel CF is calculated by multiplying litres of diesel fuel with factor 2.63 (kilograms of released $\mathrm{CO}_{2}$ per litre of used diesel).

The first phase is associated with the analysis of the applied fodder technologies in the actual soil, climate and agroecological conditions. Those conditions are defined by maximum essential spatial variability and temporal changes, which determinate the priorities of their research in the conditions of the Autonomous province of Vojvodina. The data shows that between 60 and $70 \%$ of all GHG emissions at this phase of production were emitted as a consequence of fertiliser application. Precision farming methods could decrease the quantity of applied fertiliser (and consequently GHG emission) up to $40 \%$ without a decrease in crop yield.

Phase 2: Livestock production: This phase is characterised with a high level of the applied zootechnologies' unification with dominating contrast variants of high intensity sheep breeding (imported sheep breeds as well as housing and feeding technology) with the ever reducing segment of extensive technologies of sheep breeding in the Vojvodina conditions.

In the phase of livestock production, the dominant greenhouse gases are methane and nitrous oxide. The fuel and energy consumption needed for feeding and accommodation of the animals are contributing mainly with $\mathrm{CO}_{2}$. GHG emissions in this phase are shown in Table 8, and it is evident that main emission in this phase is $\mathrm{N}_{2} \mathrm{O}$ emission from manure and that emissions from enteric fermentation and fuel and energy consumption are almost equal, which is a consequence of the high percentage of concentrated feed in daily nutritional ratio and high fuel and electricity consumption.

Methane emission as a consequence of enteric fermentation is significant in the case of ruminants. Literature data are showing that $\mathrm{CH}_{4}$ emission depends on type of animal nutrition, and that animals with more concentrated feed release less methane and vice versa [29-31]. Conducted analyses had represented intensive lowering of the methane emission from enteric fermentation with change of the seasonal grazing system with modern ones, chiefly by increasing the number of lambs per ewe and improved feed conversion efficiency, which should be included in the assessment of the modernisation projects of sheep farms.

Comparing data form Table 10 with data from European sources [7,23], it is evident that CF of production in Vojvodina region is much higher than in European countries (21.41 and $19.13 \mathrm{~kg} \mathrm{CO}_{2}$ e, compared to the 17.86 and $12.85 \mathrm{~kg} \mathrm{CO}_{2}$ e respectively), which is the consequence of improper usage of fertilisers and manure management and application. The main distinction of Vojvodina province is low efficiency of manure utilisation. GHG emissions as a result of manure handling in Vojvodina region are almost exclusively important from $\mathrm{N}_{2} \mathrm{O}$ point of view, because the main way of 
manure storage is in form of piles, completely aerated, not protected by any mean and with free emission from the manure [12]. This is the field where the implementation of the intensive technologies of manure handling, utilisation and management will significantly decrease GHG emission. Biogas production could potentially decrease GHG emissions at least by $80 \%$ (nitrous oxide emission is substituted to methane emission, and by burning, reducing GHG emission to carbon-dioxide and water vapour).

\section{Acknowledgements}

This paper is financed by the Ministry of Education, Science and Technological Development of the Republic of Serbia, Project No. 451-03-68/2020-14/ 200197.

The data on quantity of feed and agrotechnology for feed preparation, as well as nutritional needs for animals were obtained through joint work of Institute of Lowland Forestry and Environment, University of Novi Sad and Department of Field and Vegetable Crops and Department for Animal Science - Laboratory for Quality Control of Feed and Animal Products of Faculty of Agriculture, University of Novi Sad, with methodological help and supervision of experts from Russian Timiryazev State Agrarian University, Moscow, Russian Federation.

\section{Authors' contributions}

SM had performed measurement calculation of GHG emissions, determined animal weight and age, animal productivity and co-established experiment, GZ and VJ performed tests on decomposition of soil organic matter and nitrous fertilizers in the soil as well as collected samples of GHGs. JI performed calculations on feed quality, quantity, the determined energy value of feed, determined animal weight and age, animal productivity and co-established experiment. LD determined productivity of farm crops, needs for nutrients from the soil and co-established experiment. AI and VI had provided methodological support and made necessary corrections and reviews of results and the paper itself.

\section{Declaration of conflicting interests}

The author(s) declared no potential conflicts of interest with respect to the research, authorship, and/or publication of this article. 


\section{REFERENCES}

1. Bernstein L, Bosch P, Canziani O, Chen Z, Christ R, Davidson O, Hare W, Huq S, Karoly D, Kattsov V, Kundzewicz Z, Liu J, Lohmann U, Manning M, Matsuno T, Menne B, Metz B, Mirza M, Nicholls N., Nurse L, Pachauri R, Palutikof J, Parry M, Qin D, Ravindranath N, Reisinger A, Ren J, Riahi K, Rosenzweig C, Rusticucci M, Schneider S, Sokona Y, Solomon S, Stott P, Stouffer R, Sugiyama T, Swart R, Tirpak D, Vogel C, Yohe G, Barker T: Climate Change 2007: Synthesis Report. An Assessment of the Intergovernmental Panel on Climate Change, in: Allali A, Bojariu R, Diaz S, Eligizouli I, Griggs D, Hawkins D, Hohmeyer O, Jallow B.P, Kajfež-Bogataj L, Leary N, Lee H, Wratt D (Eds.). Geneva, Switzerland, IPCC; 2007.

2. Marino R, Atzori A.S, D'Andrea M, Iovane G, Trabalza-Marinucci M, Rinaldi M: Climate change: Production performance, health issues, greenhouse gas emissions and mitigation strategies in sheep and goat farming. Small Ruminant Res 2016, 135:50-59.

3. Dougherty HC, Oltjen JW, Mitloehner FM, DePeters EJ, Pettey LA, Macon D, Finzel J, Rodrigues K, Kebreab E: Carbon and blue water footprints of California sheep production. J Anim Sci 2018, 96(suppl. S3):368.

4. Samardžić M, Vasin J, Jajić I, Andreeva I, Latković D, Vasenev I: Environmental assessment of the greenhouse gases emission from poultry production in Russia's central region. J Agricult Sci Belgrade 2018, 63(3):261-270.

5. Raupach M, Marland G, Ciais P, Le Quéré C, Canadell J, Klepper G, Field C: Global and regional drivers of accelerating $\mathrm{CO}_{2}$ emissions. PNAS 2007, 104(24):10288-10293.

6. Weiss F, Leip A: Greenhouse gas emissions from the EU livestock sector: A life cycle assessment carried out with the CAPRI model. Agr Ecosyst Environ 2012, 149:124-134.

7. Jones AK: The mitigation of greenhouse gas emissions in sheep farming systems. PhD thesis, Bangor, UK, Bangor University; 2014.

8. Popp A, Lotze-Campen H, Bodirsky B: Food consumption, diet shifts and associated non-CO2 greenhouse gases from agricultural production. Global Environ Chang 2010, 20(3):451-462.

9. Gerber PJ, Steinfeld H, Henderson B, Mottet A, Opio C, Dijkman J, Falcucci A, Tempio G: Tackling Climate Change Through Livestock - A global assessment of emissions and mitigation opportunities. Rome, Italy, FAO; 2013.

10. FAO: Livestock's long shadow, environmental issues and options. Rome, Italy, FAO; 2006.

11. Samardžić M, Castaldi S, Kričković Đ, Valentini R, Vasenev I: Methodlogy of meat products' carbon footprint calculation in agroecological conditions of European Russia's Central Region. Agroekologiya 2014, 2:46-51.

12. Gridnev PI, Gridneva TT: The greenhouse gases and ammonia emission at the manure cleaning and preparing it to use process. Journal of VNIIMZH 2017, 1(25):25-33.

13. Dakpo KH, Jeanneaux P, Latruffe L: Greenhouse gas emissions and efficiency in French sheep meat farming: A nonparametric framework of pollution adjusted technologies. Eur Rev Agr Econ, 2016, 44(1):1-33.

14. Hermansen J, Kristensen T, Management options to reduce the carbon footprint of livestock products. Animal Frontiers 2011, 1(1):33-39.

15. Ševarlić M: Poljoprivredno zemljište u Republici Srbiji. Belgrade, Serbia, Statistical Office of the Republic of Serbia; 2015. 
16. Nastić L, Ivanović S, Radivojević D: Analiza visine i strukture investicionih ulaganja u ovčarske i kozarske farme u Evropskoj uniji i Republici Srbiji. J Agricult Sci Belgrade 2017, 62(1):79-88.

17. ISO. 2006. Environmental management - Life cycle assessment - Principles and framework. ISO 14040:2006(E). Geneva, Switzerland, International Organization for Standardization; 2006.

18. ISO. 2006. Environmental management - Life cycle assessment - Requirements and guidelines. ISO 14044:2006(E). Geneva, Switzerland, International Organization for Standardization; 2006.

19. LEAP: Greenhouse Gas Emissions and Fossil Energy Use from Small Ruminants Supply Chains: Guidelines for Assessment. Livestock Environmental Assessment and Performance Partnership. Rome, Italy, FAO; 2015

20. Castaldi S.: IAGRICO 2 Italian Agriculture CF calculator. Napoli, Italy, Second University of Napoli; 2013

21. IPCC: Emissions from Livestock and Manure Management 2006 Guidelines for National Greenhouse Gas Inventories. Volume 4, chapter 10: Agriculture, Forestry and Other Land Use. Land Use Change and Forestry. Geneva, Switzerland, IPCC; 2006.

22. Duffy P, Hanley E, Hyde B, O’Brien P, Ponzi J, Cotter E, Black K: Ireland national inventory report 2012. Greenhouse Gas Emissions 1990-2012. Wexford, Ireland, Environmental Protection Agency, Johnstown Castle Estate, Co.; 2014.

23. O’Brien D, Bohan A, McHugh N, Shalloo L: A life cycle assessment of the effect of intensification on the environmental impacts and resource use of grass-based sheep farming. Agr Syst 2016, 148:95-104.

24. Hillier J, Hawes C, Squire G, Hilton A, Wale S, Smith P: The carbon footprints of food crop Production. Int J Agr Sustain 2009, 7(2):107-118.

25. Ecoinvent - life cycle inventory database [www.ecoinvent.ch]

26. Cederberg C, Flysjö A, Sonesson U, Sund V, Davis J: Greenhouse gas emissions from Swedish consumption of meat, milk and eggs 1990 and 2005. SIK Report No. 793. Gothenburg, SIK Institutet för livsmedel och bioteknik; 2009, 32-36.

27. FAO and International Fertiliser Industry Association: Global estimates of gaseous emissions of $\mathrm{NH}_{3}, \mathrm{NO}$ and $\mathrm{N}_{2} \mathrm{O}$ from agricultural land. Rome, Italy, FAO and IFA; 2001, 66

28. IPCC Climate Change 2013: The physical science basis. Contribution of working group I to the fifth assessment report of the Intergovernmental panel on climate change. Cambridge, United Kingdom and New York, USA, Cambridge University Press; 2013

29. Gibbs M J., Conneely D, Johnson D, Lasse K R, Ulyatt J: $\mathrm{CH}_{4}$ emissions from enteric fermentation. Geneva, Switzerland, IPCC; 2001. [http://www.ipccnggip.iges.or.jp/public/ gp/bgp/4_1_CH4_Enteric_Fermentation.pdf]

30. Normy i raciony kormleniya sel'skohozyaystvennykh zhivotnyh, spravochnoe posobie pod redaktsiey A. P. Kalashnikova, V. I. Fisinina, V. V. Shchegliva, N. I. Kleymenova. Moscow, Russian Federation, MINSEL'HOZ, RASHN, VGNII Zhivotnovodstva; 2003.

31. Flysjö A: Greenhouse Gas emissions in milk and dairy product chains - improving the carbon footprint of dairy products. PhD Thesis, Aarhus, Denmark, Aarhus University; 2012 . 


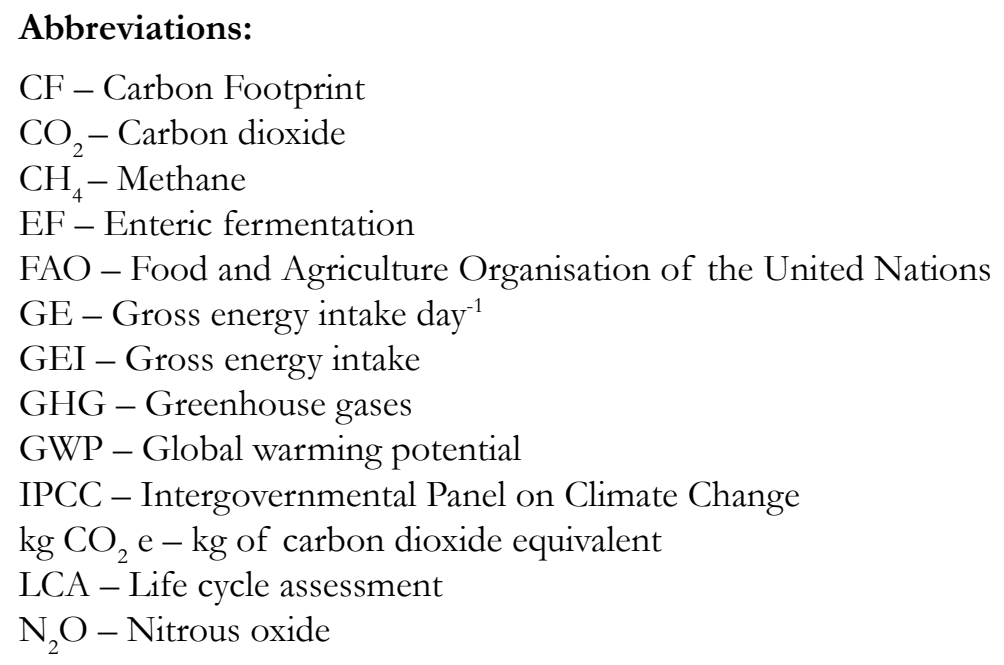

\title{
EKOLOŠKA OCENA EMISIJE GASOVA STAKLENE BAŠTE IZ OVČARSKE PROIZVODNJE NA TERITORIJI VOJVODINE
}

\author{
SAMARDŽIĆ M. Miljan, GALIĆ A. Zoran, JAJIĆ M. Igor, \\ LATKOVIĆ S. Dragana, VASIN R. Jovica, ANDREEVA V. Irina, \\ VASENEV I. Ivan
}

Cilj ovog rada je prikazivanje postupka proračuna za dobijanje procene ugljeničnog otiska $1 \mathrm{~kg}$ žive mase ovaca, ovnova i jagnjadi ,at the farm gate“, uzimajući u obzir regionalne tipološke odlike poljoprivredne proizvodnje u agro-ekosistemima. Metodologija izračunavanja otiska ugljenika (CF) zasniva se na metodologiji ocene životnog ciklusa (LCA) razvijenoj za poljoprivredne proizvode. Rezultati su pokazali da je u savremenoj tehnologiji ovčarstva u proseku ispušteno $21,41 \mathrm{~kg} \mathrm{CO}_{2} \mathrm{e} \mathrm{kg}^{-1}$ telesne težine ovaca, $19,13 \mathrm{~kg} \mathrm{CO}_{2} \mathrm{e} \mathrm{kg}^{-1}$ telesne težine ovnova, 3,2 $\mathrm{kg} \mathrm{CO}_{2} \mathrm{e} \mathrm{kg}^{-1}$ telesne težine jagnjadi. Glavna odlika ovčarstva u pokrajini Vojvodini je mala efikasnost primene mineralnih đubriva, kao i menadžment, skladištenje i korišćenje stajnjaka, što kao rezultat ima velike emisije azot-suboksida. Ovo je polje na kome će primena intenzivnih tehnologija precizne poljoprivrede kao i menadžment korištenja stajnjaka značajno smanjiti emisiju gasova staklene bašte, uz očuvanje prinosa useva i količine i kvaliteta mesa ovaca svih kategorija. 